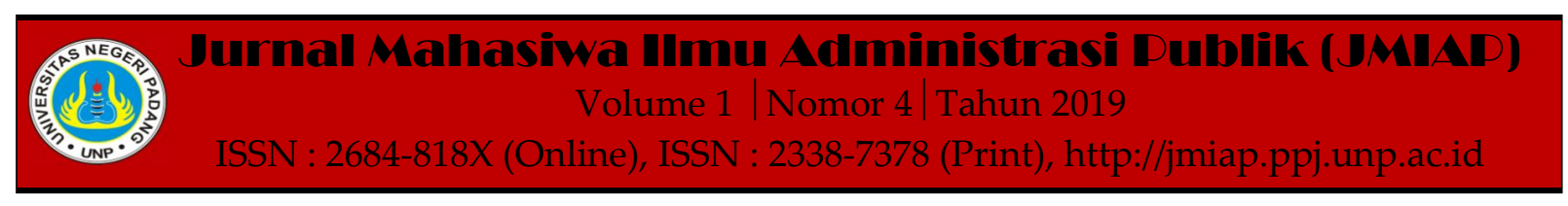

\title{
PARTISIPASI MEDIA SOSIAL UNTUK MEMPENGARUHI KEBIJAKAN PUBLIK PEMERINTAH KOTA PADANG
}

\author{
Muhammad Fadlan' ${ }^{1(a)}$, Afriva Khaidir ${ }^{2(b)}$, Nora Eka Putri ${ }^{3(c)}$ \\ ${ }^{1}$ Jurusan Ilmu Administrasi Negara, Universitas Negeri Padang \\ ${ }^{2}$ Jurusan Ilmu Administrasi Negara, Universitas Negeri Padang \\ ${ }^{3}$ Jurusan Ilmu Administrasi Negara, Universitas Negeri Padang \\ a)muhfadlan0704@gmail.com, b)af.khaidir@gmail.com, ${ }^{c)}$ noraekaputri@fis.unp.ac.id
}

\begin{abstract}
This study aims to find out how social media participation affects the policies of the Padang City government. The method in this research is a type of qualitative research with descriptive methods. The selection of informants in this study used a purposive sampling technique. The data used in this study are primary data and secondary data. Data collection techniques in this study used observation, interviews and documentation studies. Data analysis techniques in this study used data collection techniques, data reduction, data classification, data presentation, and drawing conclusions. The results of this study the authors found that social media has an influence in government policy, want it in the making, implementing and evaluating the policies of the city of Padang.

Keywords : Participation, Public Policy, Social Media

Corresponding author. Email.muhfadlan0704@gmail.com,af.khaidir@gmail.com, noraekaputri@fis.unp.ac.id

How to cite this article. Fadlan. M; Khaidir. A \& Putri. Nora Eka. (2019). Partisipasi Media Sosial untuk Mempengaruhi Kebijakan Publik Pemerintah Kota Padang. Jurnal Mahasiwa Ilmu Administrasi Publik (JMIAP) Jurusan Ilmu Administrasi Negara Fakultas Ilmu Sosial Universitas Negeri Padang, Volume 1 (4), Hal. 49-57.

http://jmiap.ppj.unp.ac.id

ISSN : 2684-818X (Online), ISSN : 2338-7378 (Print)

Copyright $@ 2019$. Published by Pusat Kajian-Pemberdayaan dan Pelayanan Masyarakat (PK-P2M) FIS UNP Padang
\end{abstract}




\section{PENDAHULUAN}

Teknologi dalam perkembangan arus produksi, konsumsi dan distribusi informasi memegang peranan penting. Urgensi peranan teknologi dalam proses informasi terjadi ketika hasil teknologi membantu mengubah pola komunikasi yang dibatasi oleh ruang dan waktu menjadi pola komunikasi informasi tanpa batas. Sehingga hadirnya media baru (new media) memberi alternatif masyarakat dalam mencari dan memanfaatkan sumber-sumber informasi untuk memenuhi kebutuhannya. Media massa konvensional (tv, radio dan cetak) dituntut adanya kemajuan teknologi, media menjadi sangat maju - selanjutnya dalam konteks ini penulis menyebut Teknologi Informasi dan Komunikasi.

Media telah berubah menjadi subyek komunikasi yang interaktif dan menjadi sahabat baru manusia. Pola interaksi sosial yang terbentuk melalui media telah menciptakan ruang baru bagi kehidupan manusia. Ruang dimana manusia bisa berimajinasi dan berinteraksi. Sementara apabila dikaitkan dalam konteks media jaringan (komputer) yang kemudian melahirkan cybercommunity (komunitas cyber) juga turut andil dalam membentuk suatu pola hubungan sosial yang tanpa batas, sangat luas dan transparan.Internet mampu memberikan layanan kecepatan informasi setiap saat, detail dan bebas biaya. Sehingga tidak lah mengherankan apabila terjadi kenaikan jumlah pengakses internet setiap tahunnya di Indonesia. Fenomena umum orang online ke internet adalah untuk mendapatkan informasi dan berbagi informasi. pada perkembangan sejarah media diIndonesia, sekarang memasuki era media-media alternatif digital seperti blog, friendsters, facebook, Twitter, Instagram, dan lain-lain (Ido Prijana, 2009).

Partisipasi politik dalam sebuah Negara demokrasi merupakan sesuatu yang substansial. Salah satu alasan yang mendasar terkait hal tersebut adalah karena salah satu indikator kualitas demokrasi ditentukan oleh tinggi dan rendah serta bagaimanapartisipasi politik tersebut dilakukan. Partisipasi politik adalah kegiatan seseorang atau kelompok orang untuk ikut serta secara aktif dalam kehidupan politik, antara lain dengan jalan memilih pimpinan negara dan secara langsung atau tidak langsung memengaruhi kebijakan pemerintah (Dwira, 2013).

Pemuda, sebagai agent of change, moral force, iron stock dan social control tentu memiliki kontribusi besar untuk mewujudkan kebangkitan bangsa. Ditambah lagi pemuda sekaligus kader intelektual untuk membagun bangsa yang nantinya akan menjabat sebagai pejabatpejabat pemerintahan. Partisipasi dari para pemuda sangat diperlukan sebab pemuda sangat berperan aktif dalam menjalakan politik di negara ini.Ragam media sosial yang tengah berkembang dan banyak diminati orang adalah Instagram, Facebook, Myspace, dan Twitter, youtube, dsb. Jika media tradisional menggunakan media cetak dan media broadcast, maka media sosial menggunakan internet. Dengan demikian, media sosial sebagai sarana komunikasi memiliki peran membawa orang (penggunanya) untuk berpartisipasi secara aktif dengan memberi kontribusi dan feedback secara terbuka, baik untuk membagi informasi maupun memberi respon secara online dalam waktu yang cepat. Media sosial, seperti Instagra, facebook, pada awalnya, cenderung berkait pada persoalan pertemanan. Namun, saat ini, mulai banyak menyinggung ke ranah politik kekuasaan pemerintahan atau negara. Perkembangan teknologi komunikasi berpengaruh secara baik terhadap proses politik. Bahkan, kemajuan komunikasi digital dengan email akan membawa pada pemberian semangat baru demokrasi (Budiyono, 2016).

Dalam aktivitas sehari-hari, tidak satu pun manusia tidak berkomunikasi, dan ketika seseorang atau sekelompok orang 
membicarakan fenomena seperti kebijakan kenaikan harga bahan bakar minyak (BBM), maka mereka sebenarnya telah mengarah pada analisis komunikasi politik. Berbagai penilaian dan analisis orang awam yang berkomentar mengenai persoalan kenaikan harga BBM, misalnya, merupakan contoh komunikasi politik. Meskipun demikian, yang kemudian berkembang bahwa media sosial tidak saja dimanfaatkan untuk halhal positif, melainkan sering dimanfaatkan untuk sarana penistaan, penghujatan, dan pencemaran nama baik seseorang agar kredibilitasnya jatuh. Fenomena tersebut jika dibiarkan akan menjadi kondisi yang kontradiktif antara kehadiran media sosial yang diharapkan mengembangkan komunikasi politik masyarakat dengan persoalan yang justru menghambat kemajuan komunikasi politik (Budiyono, 2016).

\section{TINJAUAN PUSTAKA \\ Partisipasi}

Partisipasi politik adalah kegiatan individu warga negara yang dapat diamati dan diarahkan untuk mempengaruhi pemerintah selaku pembuat sekaligus pelaksana keputusan politik. Secara konsep yang berhasil (efektif) maupun gagal mempengaruhi pemerintah, secara langsung atau tidak langsung, dan melalui prosedur wajar (konvensional) dan tidak melalui kekerasan (nonviolence) serta cara diluar prosedur yang wajar (non konvensional) dan berupa kekerasan (violence) (Surbakti, 2009).

Aspek politik partisipatif berakar dari konsep Henry Jenkins budaya partisipatif (Jenkins,2009). Dalam budaya partisipatif, partisipasi secara signifikan rekan-berbasis, interaktif, nonhierarchical, independen dari lembaga yang dikendalikan elit, dan sosial, yang dapat diakses analisisnya pada tingkat kelompok daripada individu.

Partisipasi dalam perbincangan politik kebijakan terjadi di ranah jejaring sosial atau online. Dimana aktivitas yang terjadi, yaitu (Jenkins, 2009) :
1) Investigasi: anggota komunitas aktif mengejar informasi tentang isu-isu perhatian publik, mencari, mengumpulkan, dan menganalisa informasi dari beragam sumber. (pencarian berita dan percakapan).

2) Dialog dan feedback: percakapan antar komunitas yang cenderung pada isu dan perhatian publik tentang politik. (forum, chat, komentar).

3) Sirkulasi: pertukaran aliran informasi terbentuk dari beragam komunitas publik dibanding sekumpulan elit. (pernyataan, diskusi, komentar, interaksi langsung kepada politisi) para anggota komunitas tidak hanya mensirkulasikan informasi tetapi juga membuat konten original. (video, artikel, meme).

4) Mobilisasi: Gerakan yang bertujuan menjalankan tujuan negara atau politis. (perekrutan, berkumpul, petisi).

\section{Kebijakan Publik}

Carl J. Federick sebagaimana dikutip Leo Agustino(2008: 7) mendefinisikan kebijakan sebagai serangkaian tindakan/kegiatan yang diusulkan seseorang, kelompok atau pemerintah dalam suatu lingkungan tertentu dimana terdapat hambatan-hambatan (kesulitankesulitan) dan kesempatan-kesempatan terhadap pelaksanaan usulan kebijaksanaan tersebut dalam rangka mencapai tujuan tertentu.

\section{Media Sosial}

Media sosial online, disebut jejaring sosial online bukan media massa online karena media sosial memiliki kekuatan sosial yang sangat mempengaruhi opini publik yang berkembang di masyarakat. Penggalangan dukungan atau gerakan massa bisa terbentuk karena kekuatan media online karena apa yang ada di dalam media sosial, terbukti mampu membentuk opini, sikap dan perilaku publik atau masyarakat. Fenomena media sosial ini bisa dilihat dari kasus Prita Mulyasari versus 
Rumah Sakit Omni International. Inilah alasan mengapa media ini disebut media sosial bukan media massa. (Ardianto, 2011)

\section{METODE PENELITIAN}

Penelitian ini memakai jenis penelitian kualitatif memakai metode deskriptif. Penelitian dilakukan di Kota Padang. Pemilihan informan dalam penelitian ini menggunakan teknik purposive sampling. Penggunaan sistem Purposive Sampling dalam penelitian ini supaya peneliti mendapatkan data yang valid dan maksimal. Data yang digunakan dalam penelitian ini adalah data primer dan data sekunder. Data primer diperoleh melalui wawancara dan observasi langsung dari informan. Data sekunder diperoleh melalui studi dokumentasi terhadap literatur yang dapat menunjang penelitian. Agar memperoleh hasil kredibilitas yang sangat baik maka dari itu didalam penelitian ini menggunakan bentuk pengkajian kesahan informasi yang sesuai atas pendapat (Moleong, 2006) yaitu teknik triangulasi sumber yang dilakukan dengan cara melakukan member check sampai dicapai tahap kejenuhan data. Proses analisis data dimulai dengan pengumpulan data, reduksi data, penyajian data, dan terakhir penarikan kesimpulan.

\section{HASIL DAN PEMBAHASAN}

\section{Partisipasi Dan Intensitas Media Sosial Dalam Kebijakan Publik Di Kota Padang.}

Aspek politik partisipatif berakar dari konsep Henry Jenkins budaya partisipatif (Jenkins,2009). Dalam budaya partisipatif, partisipasi secara signifikan rekan-berbasis, interaktif, nonhierarchical, independen dari lembaga yang dikendalikan elit, dan sosial, yang dapat diakses analisisnya pada tingkat kelompok daripada individu. Partisipasi dalam perbincangan politik kebijakan terjadi di ranah jejaring sosial atau online. Dimana aktivitas yang terjadi, yaitu (Jenkins, 2009):

\section{a) Investigasi}

Investigasi adalah anggota komunitas aktif mengejar informasi tentang isu-isu perhatian publik, mencari, mengumpulkan, dan menganalisa informasi dari beragam sumber pencarian berita dan percakapan. Partisipasi media sosial atau media online yang ada di Kota Padang dalam mencari pemberitaan atau kejadian dan infromasi terkait keadaan pemerintahan di Kota Padang sudah cukup tinggi.

Salah satu media online di Kota Padang yang bekerja mencari berita atau informasi tekait keadaan baik itu politik, pemerintahan, kebijakan, ataupun kejadian yang terjadi ditenga masyarakat yaitu media online harian haluan. Partisipasi media online harian halua dalam mencari berita atau informasi terkait keadaan pemerintahan Kota Padang mendapatkan informasi dari pewarta yang kemudian informasi tersebut diberikan kepada admin pengelola media online harian haluan.

Setiap informasi atau isu-isu yang masuk atau diberikan dari berbagai sumber terutama dari pewarta ataupun sumber lainnya seperti masyarakat, pemerintahan atau lembaga-lembaga lain, informasi tersebut terlebih dahulu disaring oleh admin media sosial harian haluan untuk dikonfirmasi kebenaran akan isu-isu dan informasi yang diberikan. Hal tersebut dilakukan agar informasi yang nantinya menyebar dan dibaca oleh masyarakat di media sosial adalah informasi yang merupakan kebenaran bukan hoax.

b) Dialog dan Feedback

Hasil dari partisipasi media sosial terkait investigasi berita, informasi atau isu-isu yang sedang terjadi ditengah masyarakat adalah munculnya dialog-dialog atau feedback dari netizen atau masyarakat yang membaca informasi yang di sebarkan di media sosial.

Dialog atau feedback adalah percakapan antar komunitas yang cenderung pada isu dan perhatian publik tentang politik baik 
ituberupa forum, chat, dan komentar. Partisipasi masyarakat pengikut media sosial harian haluan sangat antusias apabila ada berita terkait dengan politik dan kebijakan pemerintah, didalam postingan media harian haluanpun banyak terjadi dialog langsung antar pengkut media sosial baik itu dalam kolom komentar ataupun pesan langsung kepada admin madia sosial harian haluan maka dapat dilihat antusias masyarakat untuk ikut serta atau memperhatikan keadaan pemerintahan di Kota Padang cukup tinggi terutama generasi milenial pengguna media sosial.

Media sosial menjadi salah satu media yang digunakan oleh masyarakat Kota Padang terutama generasi muda untuk mengemukakan pendapat atau aspirasi mereka. Dengan adanya media sosial masyarakat dapat berkomunikasi langsung dengan pemerintah ataupun anggota dewan terkait keadaan pemerintahan atau permasalahan yang sedang terjadi. Dengan adanya media sosial respon dari masyarakat terkait keadaan pemerintah kota padang menjadi lebih cepat karena semuanya sudah ada didalam genggaman.

Dialog atau diskusi yang terjadi ditengah masyarakat pengguna media sosial terutama generasi milenial diharapkan menjadi dialog yang terarah dan tepat sasaran, bukan dialog yang cenderung menghujat ataupun menimbulkan propaganda sehingga terjadi perpecahan ditengah masyarakat. Oleh karena itu sangat diharapkan pengguna media sosial untuk dapat berpartisipasi dan bijak dalam menggunakan media sosial.

c) Sirkulasi

Partisipasi media sosial dalam hal kebijakan pemerintah di Kota Padang juga berada pada ranah sirkulasi informasi. Sirkulasi informasi adalah pertukaran aliran informasi terbentuk dari beragam komunitas publik dibanding sekumpulan elit. Pernyataan, diskusi, komentar, interaksi langsung kepada politisi dan para anggota komunitas tidak hanya mensirkulasikan informasi tetapi juga membuat konten original seperti video, artikel, dan meme.

Pertukaran informasi pada ranah media sosial sangat cepat terjadi atau dikenal dengan istilah repost atau memposting ulang apa yang telah diposting oleh orang lain di media sosial mereka. Dengan adanya kegiatan seperti itu informasi akan lebih cepat menyebar ditengah masyarakat pengguna media sosial.

Pertukaran informasi berupa konten original berupa video dan meme terkait isuisu yang sedang hangat terjadi ditengah masyarakat menjadi daya tarik tersendiri terutama bagi kaum milenian untuk memperhatikan keadaan pemerintahan. Postingan yang dilakukan oleh media sosial itu dapat menarik minat masyarakat terutama generasi muda atau kaum milenial apabila informasi tersebut dikemas dalam bentuk meme ataupun video. Dengan mengemas informasi dalam bentuk meme dan video akan memperoleh lebih banyak komentar dari masyarakat terutama generasi milenial.

\section{d) Mobilisasi}

Hasil akhir dari partisipasi media sosial dalam mempengaruhi kebijakan pemerintah terutama di Kota Padang adalah mobilisasi. Mobilisasi adalah gerakan yang bertujuan menjalankan tujuan negara atau politis seperti melakukan tindakan perekrutan, berkumpul, atau hanya sekedar mengumpulkan petisi.

Informasi yang disebarkan dimedia sosial terkait keadaan pemerintah dan kebijakan pemerintah Kota Padang yang apabila dikemas dengan sangat baik berupa video atau meme sehingga dapat menarik minat banyak orang terutama generasi milenial untuk ikut berkomentar dan berpendapat terkait isu tersebut. Pada akhirnya komentar atau pendapat yang membentuk sebuah dialog di media sosial dapat memolisasi masyarakat untuk membentuk sebuah petisi ataupun 
melakukan aksi untuk menentang kejadian yang sedang terjadi.

Kasus yang sedang hangat terjadi pada saat ini yang merupakan bukti nyata dari dampak media sosial terhadap pemerintah Kota Padang adalah dengan banyaknya masuk wisatawan dari Cina ke Sumatera Barat ditenga menyebarnya virus corona di negara Cina. Hal terebut menimbulkan kegelisahan ditengah masyarakat dan masyarakat beramai-ramai menolak ataupun menentang hal tersebut dan meminta pemerintah untuk secepatnya mengusir wisatawan dari Cina untuk pergi dari Sumatera Barat.

Media sosial dapat memobilisasi masa untuk melakukan tindakan ataupun petisi yang menentang pemerintah namun tetap selaku masyarakat harus memahami terlebih dahulu apa yang sedang terjadi dan kritik yang disampaikan kepada pemerintah diharapkan tepat sasaran, karena pemerintah tidak membatasi masyarakat untuk berpendapat.

\section{Faktor Yang Mempengaruhi Pembuatan Kebijakan Publik Di Kota Padang.}

Pembuatan kebijakan dipengaruhi oleh beberapa faktor. Hal penting yang turut diwaspadai dan selanjutnya dapat diantisipasi adalah dalam pembuatan kebijakan sering terjadi kesalahan. Faktorfaktor yang mempengaruhi pembuatan kebijakan adalah:

\section{a) Faktor Internal}

Faktor internal adalah faktor yang mempengaruhi pembuatan kebijakan yang berasal dari dalam lingkungan organisasi ataupun pemerintahan. Adanya pengaruh sifat-sifat pribadi Berbagai keputusan/kabijakan yang dibuat oleh para pembuat keputusan/kebijakan banyak dipengaruhi oleh sifat-sifat pribadinya. Sifat pribadi merupakan faktor yang berperan besar dalam penentuan keputusan/kebijakan.
Dalam merumuskan sebuah kebijakan DPRD Kota Padang membangun sinergi dengan berbagai pihak terutama pemerintah Kota Padang, tokoh masyarakat, dan harus melalui berbagai proses musyawarah atau musrembang, oleh karena itu banyak stakeholder yang dapat mempengaruhi dapat pembuatan kebijakan.

Pengaruh stakeholder yang berada didalam lingkungan pemerintahan dalam merumuskan kebijakan tidak jarang terjadinya atau membawa kepentingan individu ataupun kepentingan kelompok dalam merumuskan sebuah kebijakan yang akan menguntungkan segelintir orang. Oleh karena itu diharapkan dalam merumuskan sebuah kebijakan dapat dilakukan dengan mempertimbangkan keadaan masyarakat sehingga kebijakan tersebut memang dapat bermanfaat dan diterima oleh masyarakat banyak.

\section{b) Faktor Eksternal}

Faktor eksternal adalah faktor yang mempengaruhi dalam pembuatan kebijakan yang berasal dari luar lingkungan pemerintahan baik itu seperti masyarakat, lembaga-lembaga swasta, dan media sosial. Adanya pengaruh tekanan-tekanan dari luar seperti media sosial tidak jarang pembuat kebijakan harus memenuhi tuntutan dari luar atau membuat kebijakan adanya tekanan-tekanan dari luar.

Proses kebijakan publik berlangsung dalam suatu sistem politik yang dipengaruhi oleh lingkungannya. Input kebijakan berasal dari lingkungan dalam bentuk tuntutan politis, yang berkembang menjadi isu kebijakan yang diproses sampai akhirnya menjadi keputusan kebijakan. Demikian pula proses kebijakan pendidikan, sebagai bagian dari kehidupan kenegaraan, maka juga tidak dapat dilepaskan dari sistem politik dan lingkungannya.

Adanya pengaruh dari kelompok. Adanya pengaruh dari kelompok luar Lingkungan sosial dari para pembuat 
keputusan/kebijakan juga berperan besar seperti media sosial. media sosial dapat mempengaruhi atau menjadi faktor ekternal yang mempengaruhi kebijakan pemerintah. Melalui media sosial melakukan postingan terkait keadaan pemerintahan atau kebijakan pemerintah dan mendapatkan beragam komentar dari masyarakat dan hal itupun dibaca oleh pihak pemerintah terkait maka hal tersebut dalam menjadi pertimbangan oleh pemerintah untuk menghambil kebijakan kedepan atau perubahan dalam pelaksanaan pemerintahan.

Contoh pemgaruh media sosial dalam mempengaruhi kebijakan pemerintah Kota Padang dalam merumuskan kebijakan yang akan diambil oleh pemerintah Kota Padang media sosial memiliki pengaruh, seperti kebijakan atau agenda pemerintah terkait permindo Night Market yang mana agenda atau kegiatan tersebut dihasilkan melalui hasil diskusi dengan generasi muda dan feedback yang terdapat dalam media sosial.

Kebijakan pemerintah Kota Padang yang diambil berdasarkan pengaruh atau wacana yang ada di media sosial masyarakat Kota Padang yaitu terkait dengan sulitnya pelaku usaha melakukan investasi, kemudian menyikapi hal tersebut pemerintah Kota Padang mengeluarkan kebijakan investasi daerah. Dan permasalahan yang sedang viral banyaknya makanan yang mengandung bahan haram maka pemerintah Kota Padang mengeluarkan kebijakan terkait label halal pada setiap produksi makanan

\section{PENUTUP}

Berdasarkan hasil analisis yang dilakukan terhadap data penelitian guna mengungkap dan menjawab pertanyaanpertanyaan penelitian terkait Partisipasi Media Sosial Untuk Mempengaruhi Kebijakan Pemerintah Kota Padang, maka dapat peneliti simpulkan:
1) Partisipasi media sosial dalam kebijakan publik di Kota Padang, Pertama investigasi dengan

mengumpulkan isu-isu atau informasi terkait kedaan pemerintahan Kota Padang yang bersumber baik dari pewarta ataupun masyarakat. Kedua membangun dialog atau fedback yang terjadi di media sosial terkait isu yang sedang hangat terjadi berupa komentarkomentar oleh masyarakat didalam postingan media sosial. Ketiga sirkulasi informasi yang menjadi daya tarik masyarakat adalah dengan adanya meme atau video terkait isu yang sedang terjadi ditengah masyarakat. Keempat admin media sosial dapat memobilisasi atau mengumpulkan masa dengan melakukan postingan di media sosial yang pada akhirnya mengahasilkan sebuah gerakan atau aksi.

2) Ada beberapa faktor yang mempengaruhi pembuatan kebijakan di Kota Padang, Pertama Faktor internal adalah faktor yang berasal dari dalam organisasi pemerintahan seperti adanya pengaruh kepentingan baik itu individu ataupun kelompok didalam perumusan kebijakan. Kedua Faktor eksternal adalah faktor yang berasal dari luar lingkungan perumus kebijakan atau pemerintah Kota Padang dimana media sosial menjadi faktor yang mempengaruhi dalam permusan kebijakan ataupun program-program pemerintah Kota Padang.

\section{DAFTAR KEPUSTAKAAN}

Abdul Wahab, Solihin. 2008. Analisis Kebijakan : Dari Formulasi ke Implementasi Kebijakan Negara Edisi Kedua. Bumi Aksara. Jakarta.

Agustino, Leo. 2008. Dasar-Dasar Kebijakan Publik. Alfabeta. Bandung.

Prastowo, Andi. 2011: Metode Penelitian Kualitatif Dalam Perspektif Rancangan Penelitian. Ar-Ruz. Yogyakarta.

Ann Seidman, Robert B. Seidman dan Malin Abeyserkere. 2001 : Penyusunan 
Muhammad Fadlan, Afriva Khaidir, Nora Eka Putri| Partisipasi Media Sosial untuk Mempengaruhi Kebijakan Publik Pemerintah Kota Padang

Rancangan Undang-Undang Dalam

Perubahan Masyarakat Yang

Demokratis. Proyek ELIPS

Departemen Kehakiman Dan Hak Asasi Manusia Indonesia.

Ardiyanto. 2011 : Komunikasi 2.0. Mata Padi Perssindo. Yogyakarta.

Winarno, Budi. 2007. Kebijakan Publik : Teori Dan Proses Edisi Refisi. Media Persindo. Yogyakarta.

Budi Yono. 2016 : Media Sosial Sebagai Komunikasi Politik Menjelang Pilkada DKI Tahun 2017 “ Jurnal Komunikasi No. 1, Vol. 1. 2016.

Kharisma, Dwira. 2013 : Peran Pendidikan Politik Dalam Partisipasi Politik Kalangan Muda. Hasil Penelitian.

Suhardono, Edi. 1994 : Teori Peran (Konsep, Derifasi Dan Implikasinya). PT. Gramedia Pustaka Utama. Jakarta.

Flew, Terry. 2002 : New Media An Intruduction New York. Oxford University Press.

Prijana, Ido. 2009 : "Perkembangan Teknologi Komunikasi Dalam Era Jurnalistik Modern" Jurnal Ilmiah Scriptura, No. 1, Vol. 3.

Jenkins, Henry. 2006 : Converge cullture : Where Old And New Media Collide. New York. New York University Press.

Moleong, Lexy J. 2005 : Metodologi Penelitian Kualitatif. Remaja Rosda Karya. Bandung.

Hadjon, Philipus M. 1987 : Perlindungan Hukum Bagi Rakyat Indonesia. PT. Bina Ilmu. Surabaya.
Pigram Dan Jenkins. 2009 : The Entertainment Industri : An Introduction.

Utomo, Sad Dian. 2003 : "Partisipasi Masyarakat Dalam Pembuatan Kebijakan", Dalam Indra J. Piliang, Dendi Ramdani dan Agung Pribadi, Otonomi Daerah : Evaluasi Dan Proyeksi. Divisi Kajian Demokrasi Lokal Yayasan Harkat Bangsa. Jakarta.

Sarlito. 2015 : Teori-Teori Psikologi Sosial. Rajawali Pers. Jakarta.

Sugiyono. 2004 : Metode Penelitian. Alfabeta. Bandung.

Suharno. 2009 : Dasar-Dasar Kebijakan Publik. UNY Press. Yogyakarta.

Tangkalisan, Hesel Nogi. 2003 : Implementasi Kebijakan Publik. Lukman OffsetYPAPI. Yogyakarta.

Warsono. 2014 : "Partisipasi Politik Remaja Pada Pemilu Mojokerto Tahun 2010" Jurnal Moral Dan Kewarganegaraan No. 2, Vol. 1.

Winarno, Budi. 2002 : Kebijakan Publik : Teori Dan Proses Media Presindo. Yogyakarta.

Yovinus. 2018 : Peran Komunikasi Publik Media Sosial Dalam Implementasi Kebijakan Keterbukaan Informasi Publik Di Kota Bandung. Jurnal Academia Praja No. 1, Vol. 1.

https://www.harianhaluan.com/news/detail /ambil-alih-lahan-petani-surat-edarangubernur-sumbar-diprotes-netizen.

https://id.wikipedia.org/wiki/Kota_Padang. https://tribunpangan.com/?p=2545. 
Muhammad Fadlan, Afriva Khaidir, Nora Eka Putri| Partisipasi Media Sosial untuk Mempengaruhi Kebijakan Publik Pemerintah Kota Padang

https://id.wikipedia.org/wiki/Pemberdayaa n_masyarakat.

http://teoripemberdayaan.blogspot.co.id/20

12/03/konsep-definisi-dan-teori-

pemberdayaan.html 